\title{
The Effect of Organizational Commitment and Employee Engagement towards Employee Performance through Organization Citizenship Behaviors
}

\author{
Gielhan Abraham Rembet ${ }^{1}$, Achmad Firdiansjah ${ }^{2}$ \& Sutriswanto $^{3}$ \\ ${ }^{1,2,3}$ University Of Merdeka Malang \\ Indonesia
}

\begin{abstract}
This study aims to examine the relationship between variables consisting of organizational Commitment, employee engagement, Organizational Citizenship Behavior (OCB), and Employee Performance. The mediating role of Organizational Citizenship Behavior $(O C B)$ explains to analyze the results directly or indirectly. Methodology - Research respondents are permanent employees of Bank Sulut Go in the Java area. A total of 73 respondents sampled in this study. The analysis technique is descriptive and linear regression for confirmation on a structural equation model built by the researcher and path analysis. The quantitative approach was chosen to explain the influence between research variables. Data collection using online questionnaires. Research Findings - The results show that organizational commitment and employee engagement with employee performance through mediation Organizational Citizenship Behavior (OCB) have a significant effect. Then Organizational Citizenship Behavior $(O C B)$ on employee performance also has a significant effect. The organizational commitment to employee performance and employee engagement to employee performance has no significant effect. At the same time, organizational commitment to employee performance and employee engagement with employee performance has a significant effect. Originality Research makes organizational commitment variable on employee performance and does not significantly influence the originality of this study. Several previous researchers who tested organizational commitment variables on employee performance showed a significant effect, so the research results have differences that complement theories for future research.
\end{abstract}

Keywords: Commitment, Employee Performance, Citizenship Behavior.

\section{INTRODUCTION}

One of the main factors in facing change and competition in the digital era, namely qualified and quality human resources is the key to organizational success. Employees are a unique asset in an organization because they are the only living asset and require special treatment to be loyal and give maximum contribution to the organization or company. According to Snell and Bohlander in the book Principles of Human Resources Management, quoted by Oktriandini (2015)[15], human resources are intangible. They cannot be the same as organizing organizations, organizing work, products, and technology. The success or failure of the performance achieved by the organization is influenced by the performance level of employees individually or in groups, where performance measured by instruments developed in studies that depend on general performance measures, then translated into necessary behavioral assessments which can include various things, namely: quantity of work, quality of work, opinions or statements conveyed, decisions taken in carrying out work and job descriptions. Therefore, employee performance reflects the employee's ability to perform specific skills (Sinambella, 2012)[25].

The performance of an employee can see from their commitment to the organization or often called organizational commitments, which is an emotional connection that employees feel at work and their organization. Furthermore, according to Wibowo (2015)[28], organizational commitment can be reflected in the feelings, attitudes, and behavior of individuals identifying themselves as part of the organization, being involved in the process of organizational activities, and being loyal to the organization in achieving organizational goals. High commitment can affect the level of performance and high employee loyalty to the organization, so it tends to make employees stay for a relatively long time. According to Zelvia (2015), organizational commitment is a condition in which employee sides with a particular organization and its goals and desires to maintain membership. 
Also, there is Employee Engagement, which is one way to measure employee performance, such as the opinion of Hermawan (2011) that employee engagement makes employees have high loyalty. On the contrary, employee loyalty can see in the performance of these employees, which generally have a high sense of responsibility and comply with organizational rules. Many studies use the term engagement or engagement as a variable. However, unfortunately, there is still no clear definition of the term engagement. Engagement generally defines as an attitude of enthusiasm, effort, enthusiasm, dedication, energy, and so on. The terms of employee engagement or work engagement alternately used when describing engagement or engagement. However, employee engagement refers to the relationship between employees and their organization. In contrast, work engagement refers to the relationship between employees and their jobs (Schaufeli, 2013).

The organizations believe that achieving success requires excellent individual performance to affect the organization's overall performance. Therefore, a formal job description is fundamental as a guide for the work to be completed. However, jobs that are not described in the job description are also essential for the organization's activities. Performance can be realized well because employees contribute actively to the company, have the extraordinary organizational commitment, and show positive Organizational Citizenship Behavior (OCB). OCB represents human nature that is friendly and loyal to the actions to safeguard the organization's wealth. The emergence of constructive opinions to develop the organization, the willingness to develop their skills and responsibilities, create a pleasant climate in the organization and develop collaborative activities through work culture formed from scratch (Podsakoff, 2000)[18].

As for employee involvement, organizational commitment, OCB, and performance are new issues to study. Organizations currently need employees who can work totally and loyally to create excellent performance and be taken into account by organizations, especially in the banking industry in today's digital economy, where sophisticated computers and artificial intelligence technology replace the role of humans.

According to Luthans (2011), Organizational Citizenship Behavior (OCB) reflects on the personality and attitudes or behavior of organizational members. Wibowo (2016) states that organizations want employees who are willing to volunteer to do things that are more than what is in the job description. According to Hojoops (2013), Organizational Citizenship Behavior (OCB) is a new concept for analyzing employee job satisfaction. In essence, if employees are satisfied with the organization, they will voluntarily help other employees/employees without asking for anything in return. Not all employees apply OCB in the workplace. Therefore, many organizations or companies believe that employee engagement/involvement, organizational commitment, and OCB can have an impact on improving employee performance. Thus the performance of employees/employees is a reflection of the real contribution made by employees/employees to an organization or company. Employee performance is the result of work quality and quantity achieved by an employee/employee in carrying out their duties by the responsibilities assigned to them (Suhartini, 2013).

Organizational success can measure the effectiveness of employee performance in service. According to Bishop (2000), a good employee or employee performance can be a determinant of the success of an organization in achieving its goals in its vision and mission. Nina et al. (2012)[9] stated that performance is a series of individual behaviors and activities following the organization's expectations or goals. Thus human resources are the driving force for the success of an organization. Employees/employees are required to maximize the performance they have in the organization. A person's performance is a measure of the extent to which a person is successful in doing his job duties.

Employee performance defines as the achievement of tasks, where employees at work must be following the organization's work program to show the level of organizational performance in achieving the vision, mission, and goals of the organization (Hakim, 2014)[7]. Overview of the results of achieving targets in the company or organization measuring useful performance to see the extent to which employees can adapt and run all services that have been developed by the banking organization, so that management can measure the contribution of each employee in the achievement or realization of the targets set in the Bank Business Plan (RBB) which are periodically reported to the holder. Shares and the Financial Services Authority (OJK).

Based on the description above, it can identify that improving employee performance requires organizational commitment, employee engagement, and Organization Citizenship Behaviors (OCB). As for the formulation of the problem raised in this research, how is Organizational Commitment and Employee Engagement on Employee Performance at PT? Bank SulutGo Java Area through Organization Citizenship Behaviors? The results of this study have a theoretical contribution or benefit, namely to explain a research model on employee performance studies with various driving factors or determinants that influence it, for example, organizational commitment through research by Swati and Archana (2019)[27], employee engagement through research by Zayas et al. (2015), or OCB through the research of Indarti et al. (2017)[11]., And practical benefits, namely the results of this study to make better policies regarding the management and development of human resource management system factors as well as proper regulations for the banking business environment. 


\section{LITERATURE REVIEW}

According to Wibowo (2015)[28], commitment is a person's willingness to bind himself and show loyalty to the organization because he feels he is involved in organizational activities. Organizational commitment is equal degrees for organizational members to obtain tasks and carry them out for the same purpose (Sopiah, 2008). Organizational commitment can be an attitude in explaining both the likes and dislikes of individual organizations. By Robbins (2011), Organizational Commitment is a condition in which an employee sides with a particular organization and the goals of his desire to maintain membership in that organization.

The existence of a sense of partisanship of employees towards the organization, the willingness of employees to work hard and a strong desire, have proven how strong organizational commitment is in employees. A strong sense of trust, willingness, and desire will foster a sense of belonging, involvement, and engagement of employees with the organization, which has an impact on improving employee performance in achieving organizational goals.

Employee engagement itself is defined as a favorable treatment by employees of the organization. The values in the organization and employees who are engaged in their work are aware of the goals of the organization, work, work environment to improve job performance (Robbins, 2006)[22]. Anita (2014)[3] also states that employees are one of the factors that cannot be duplicated or imitated by competitors and consider the most valuable assets if managed and appropriately involved.

Schaufeli et al. (2003)[24] stated that there are several characteristics of employees who are engaged with their work, such as having confidence in their abilities and having the opinion that "work is fun." Characterized by a high level of energy, resilience, a desire to try, and not give up in the face of challenges. Dedication is characterized by feeling valued, enthusiastic, inspiring, valuable, and challenging. A complete concentration on a task characterizes absorption. (Schaufeli \& Bakker, 2004). An employee or employee who has a high level of engagement in the organization has an understanding and concern for the operational environment of the organization, is enthusiastic at work, can work together with other employees, speaks positively about the organization, and exceeds organizational expectations.

The term Employee engagement was first introduced by William Khan in 1990, which states that engagement is the use of members of an organization for their job roles by using and expressing themselves physically, cognitively, and emotionally while carrying out their roles in the organization. Macey et al. (2009)[12] (in Asiyah, 2012) define employee engagement as an employee's appreciation of goals and energy concentration, which appears in the form of initiative, adaptation, effort, and persistence for the future, as well as resistance in the organization.

Schaufeli and Bakker (2010)[23] define employee engagement as a positive, meaningful, and motivational attitude characterized by vigor, dedication, and absorption. Meanwhile, Rothbard (2013) defines engagement as psychological involvement, which further involves two essential components, namely attention and absorption. Attention refers to the availability of cognitive and total time spent by an employee in thinking about and carrying out his role, while absorption is interpreting the role and refers to the intensity of an employee's focus on the role in the organization.

Organizational Citizenship Behavior, abbreviated as OCB, is the behavior of employees or organizational members that is voluntary outside the job description and is not regulated in company regulations, but is very beneficial for the company because it can increase organizational effectiveness and efficiency and is not related to a formal reward system. Kumar et al. (2009) define Organizational Citizenship Behavior as individual behavior that contributes to the creation of organizational effectiveness and is not directly related to the organizational reward system.

Organizational Citizenship Behavior (OCB) was first introduced by Organ et al. (1988). The same concept has also introduced Bamard (1938) called willingness to cooperate (Willingness to Corporate) and by Katz (1964), who called it innovative and spontaneous behavior (Innovative and Spontaneous Behaviors). According to Organ et al. (2006), Organizational Citizenship Behavior is the behavior of individuals who have the freedom to choose, which is indirectly or not explicitly associated with the reward system and contributes to the effectiveness and efficiency of organizational functions.

According to Mangkunegara (2012), performance is the result of work in quality and quantity achieved by an employee in carrying out his duties following the company's responsibilities. According to Dessler (2006), employee performance is work performance, namely the comparison between work results in real terms with the work standards set by the organization. Then Robbins (2008) defines performance, namely a result achieved by employees in their work according to specific criteria that apply to a job. Then according to Bangun (2012) suggests that performance is a result of work achieved by a person based on job requirements.

Mangkunergara (2011) suggests a definition of performance as an achievement in the form of work results both in quality and quantity achieved by an employee in carrying out his duties according to the responsibilities given to him. 
International Journal of Advances in Scientific Research and Engineering (ijasre), Vol 6 (9), September -2020

\section{RESEARCH METHODS}

In this study, the population to be used are permanent employees of PT. Bank SulutGo Java Area in Jakarta, Surabaya and Malang branches has a relatively small population of 73 people.

The analysis technique of this research is path analysis to explain the phenomenon under study (Nafi, 2017), predicting the value of the dependent variable $(\mathrm{Y})$ based on the value of the independent variable $(\mathrm{X})$, the determinant factor, namely determining which independent variable $(\mathrm{X})$ has the dominant effect on the dependent variable $(\mathrm{Y})$, also can use to explore the mechanism (paths) of the effect of the independent variable $(\mathrm{X})$ on the dependent variable $(\mathrm{Y})$ and to test the model using the multiple regression method with the formula:

$\mathrm{Y} 1=\mathrm{b} 1 \mathrm{X} 1+\mathrm{b} 2 \mathrm{X} 2+\varepsilon$

\section{RESULT AND DISCUSSION}

Based on the test results above, it is known that the Tolerance value of all variables is $>0.1$ and the VIF value $<10$, so there is no multicollinearity in this study.

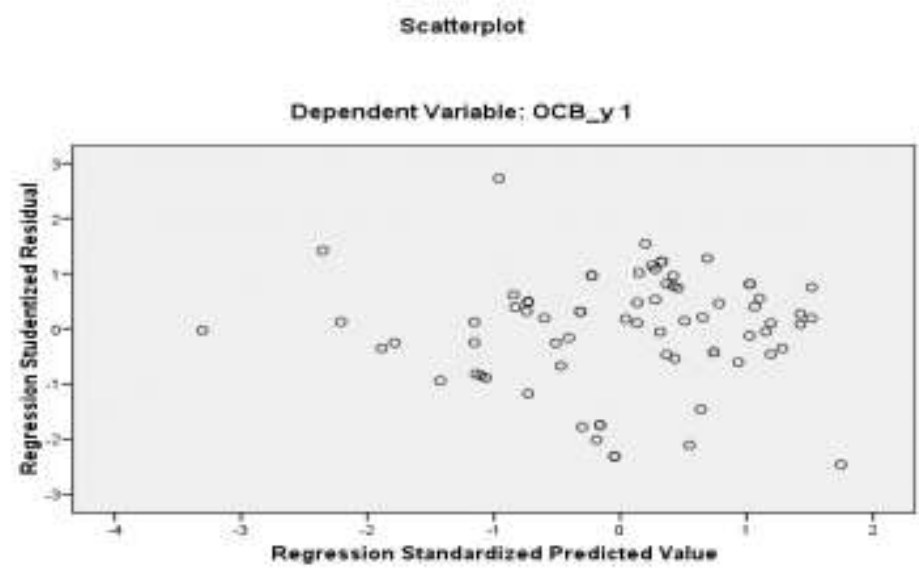

Figure 1 Heteroscedasticity test

\section{Heteroscedasticity test}

Based on the picture above, the dots are evenly distributed, do not form a sure visible arrangement, and spread between the 0 points, both top and bottom. Explains that there is no heteroscedasticity in this equation. The effect of Organizational Commitment and Employee Engagement on Employee Performance through OCB shows the indirect influence that occurs between the role of organizational commitment and employee engagement on employee performance results by mediating OCB behavior, showing significant results. Commitment to the organization and employee engagement through OCB behavior has shown an attitude that is more than just formal membership because it includes an attitude of liking the organization and a willingness to make every effort for the benefit of the organization for the achievement of goals, where employees who have these attitudes tend to have high dedication, significant responsibility for performance and the results of their work.

According to Meyer \& Allen (1994), employees with high organizational commitment will work with dedication, making these employees have a strong desire to give more energy and responsibility to support the welfare and success of the organization where they work. The forms of organizational commitment from the results of this study are the strength of a person's desire to work for an organization or company because he agrees with the goals of the organization and wants to do so, the strength of a person's desire to continue his work for the organization because he needs work and cannot do it. Another job is a person's strong desire to continue his work for the organization because he feels an obligation from others to be maintained. Besides, Schaufeli and Bakker (2003)[24] explain that the aspects that build the dimensions of employee engagement are strength, dedication, and absorption. Is refers to feelings of enthusiasm, inspiration, pride, and a willingness to face challenges - this absorption is characterized by complete concentration, interest in work, and reluctance to give up from work.

OCB behavior in the view of Organ (2006) is the behavior of helping colleagues in completing their work, behavior that is willing to accept unpleasant conditions, which are less than ideal, and responsible behavior to participate in corporate life activities which of course can significantly affect the positive performance of employees. Based on the explanation above, 
organizational commitment includes elements of loyalty to the organization, involvement in work, and identification of organizational values and goals. While highly committed employees are responsible for all their actions, these attitudes and behaviors affect OCB and have an impact on employee performance.

This research occurs due to several factors, as follows; Bank SulutGo management ability in fulfilling good welfare, employee turnover is meager, most of the employees of Bank SulutGo in the Java area are employees / permanent employees, the majority of employees are employees who have worked for more than 5 (five) years or are senior employees. This study proves that organizational commitment and employee engagement in employee performance results with OCB mediation are significant.

Multiple linear regression analysis strength of influence between the variables of Organizational Commitment, Employee Engagement, OCB, and Performance, besides this analysis, can explain the relationship between the independent and dependent variables of this study. The following analysis results obtained:

$$
\mathrm{Y} 1=\alpha 1+\beta 1 \mathrm{X} 1+\beta 2 \mathrm{X} 2
$$

Multiple linear regression analysis to determine the influence of organizational commitment and employee engagement on OCB.

This operational limitation is a constructive affirmation of meaning so as not to provide a bias in research. Because basically, a variable will be natural to measure when the parameters or indicators are clear. This research discussion requires several operational definitions of variables, which are operational problem boundaries, where the definition for each variable and the variable indicator is Organizational Commitment is a condition in which an employee side with a particular organization and the goals of his desire to maintain membership in the organization.

Employee engagement is a positive attitude that employees have towards the organization and its values for achieving organizational goals. Organizational Citizenship Behavior (OCB) is a voluntary behavior in carrying out or assisting tasks outside the predetermined job description with the primary goal of organizational interests. Employees' performance is a work performance or an outcome achieved by employees in their work according to specific application criteria.

Table 1 Results of Multiple Regression Analysis

\begin{tabular}{|c|c|c|c|c|c|c|}
\hline \multirow{2}{*}{\multicolumn{2}{|c|}{ Model }} & \multicolumn{2}{|c|}{$\begin{array}{c}\text { Unstandardized } \\
\text { Coeff icients }\end{array}$} & \multirow{2}{*}{$\begin{array}{c}\text { Standardized } \\
\text { Coefficients } \\
\text { Beta }\end{array}$} & \multirow[b]{2}{*}{ t } & \multirow[b]{2}{*}{ Sig. } \\
\hline & & $\mathrm{B}$ & Std. Error & & & \\
\hline \multirow[t]{3}{*}{1} & (Constant) & 5.978 & 7.276 & & .822 & .414 \\
\hline & Komitmen Organisasi_x1 & .428 & .161 & .266 & 2.656 & .010 \\
\hline & Keterikatan Karyawan_x2 & 1.100 & .221 & .498 & 4.986 & .000 \\
\hline
\end{tabular}

a. Dependent Variable: OCB_y 1

The table shows the coefficient results for the independent variable Organizational Commitment $(\mathrm{X} 1)=0.428$ while Employee Engagement $(\mathrm{X} 2)=1,100$ as the constant a $=5,978$ so that the multiple linear regression equation models that formed is:

$$
\mathrm{Y} 1=5,978+0.428 \mathrm{X} 1+1,100 \mathrm{X} 2
$$

The table above shows the coefficient results for the independent variable Organizational Commitment $(\mathrm{X} 1)=-0.127$ while Employee Engagement $(\mathrm{X} 2)=1.406$ as for the constant a $=22,978$ so that the multiple linear regression equation models that formed is:

$$
\mathrm{Y} 1=22,978+-0,127 \mathrm{X} 1+1,406 \mathrm{X} 2
$$

The table above shows the coefficient results for the independent variable OCB $(\mathrm{Y} 1)=0.562$ as for the constant a = 35.653 so that the simple linear regression equation model that formed is:

$$
\mathrm{Y} 2=35,653+0.562
$$

The table above shows the Sig. (significance) of $=0.000$, if the value is Sig. $<0.05$, then H0 is rejected, which means that the relationship between variables is significant. That the OCB variable has a significant effect on employee performance. 
Path analysis in this study used to calculate the independent variable's direct and indirect effect on the dependent variable. This influence can from the coefficient value and significance value. The following are the results of the path diagram of this study.

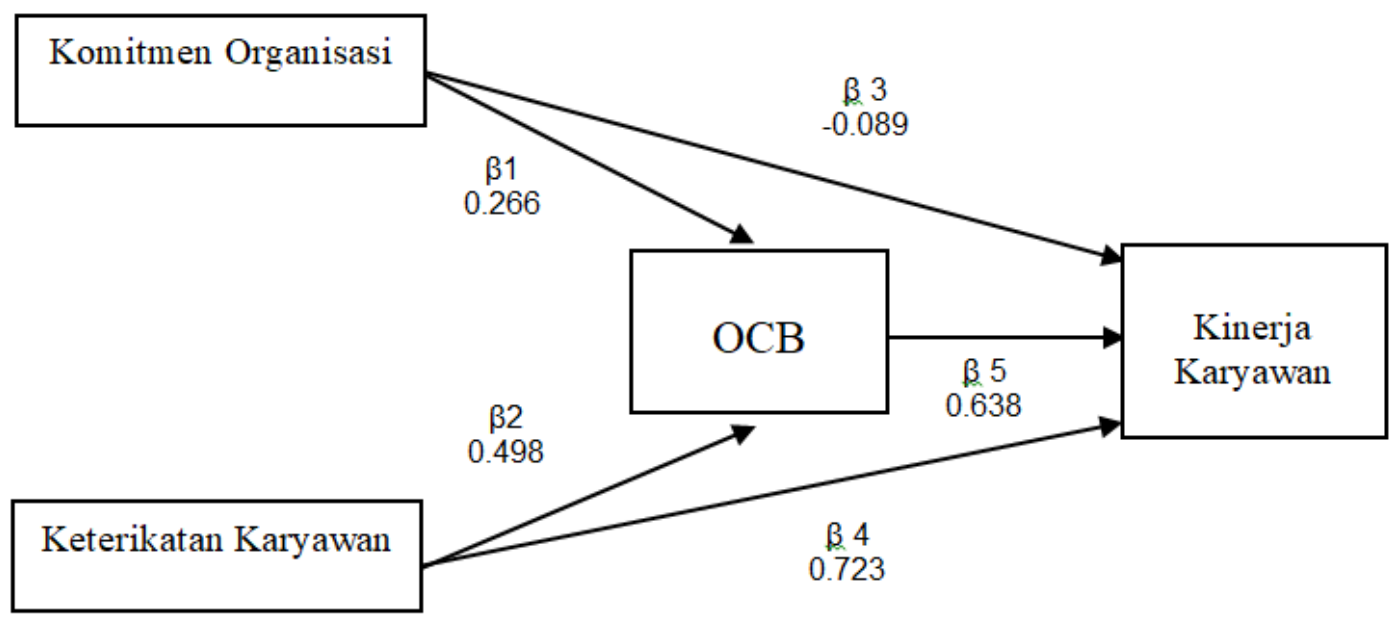

Figure 2 Path Analysis Result Diagram

\section{CONCLUSION}

This study is about the influence of organizational commitment and employee engagement on employee performance through OCB for employees of PT. Bank SulutGo in Java Area in Jakarta, Surabaya and Malang Branches. The reason for choosing the location is because employees in the Java Island area have their uniqueness as regional bank branches, namely Sulawesi and Gorontalo which are expanding on the island of Java, of course, the differences in the cultural character of the social environment and the character of the different employees between the central and branch offices. This research was also conducted in order to test and compare findings in the field with existing theories. In this thesis study, the researcher discusses five problems: How the influence of Organizational Commitment and Employee Engagement on Employee Performance at PT. Bank SulutGo Java Area through Organization Citizenship Behaviors?

The number of samples used is 73 permanent employees. The sampling technique is saturated because the total population is 73 employees. With a quantitative research approach, the study collects data through offline and online questionnaires. Also, the analysis technique used is path analysis. In this study, organizational commitment comes from individual evaluations of work situations in an organization that encourage followers to become more committed to the task, which leads to higher levels of employee performance as in several previous studies. In contrast, in this study, a significant relationship was not tested.

Other results show the effect of employee engagement on employee performance. All of the characteristics contained in employee engagement are related to the efforts made by business organizations (companies) in general, to improve employee performance. In the results of a survey of employees of Bank SulutGo in the Java area, it is known that dedication, strength, and work activeness factors can have a significant effect on improving employee performance. This means that the management of Bank SulutGo has made various efforts to increase employee engagement. This is also evidenced by the results of a survey where most employees want to end their careers at Bank SulutGo up to their retirement age limit. The next result, OCB has a significant effect. OCB represents the nature of employees or employees who are friendly, willing to sacrifice, and full of mutual enthusiasm in supporting the progress of the company or organization. In the final part, this study shows the indirect effect that occurs between the role of organizational commitment and employee engagement on employee performance mediated by OCB shows a significant effect.

\section{REFERENCES}

1. Anwar, AA dan Prabu Mangkunegara. 2012. Evaluasi Kinerja Sumber Daya Manusia. Bandung: PT. Refika Aditama

2. Allen, N. J. \& Meyer, J. P. (1997). Organizational commitment: Evidence of Career Stage Effects. Journal of Business Research, 26, 49-61. 
3. Anita. J (2014). Determinants of Employee Engagement and Their Impact on Employee Performance. Emerald Group Publishing Limited, 63, 308-323. doi:10.1108/IJPPM-01-2013-0008

4. Arikunto. 2007. Metode Penelitian Kuantitatif. Jakarta: Salemba Empat.

5. Cendani, C., \& Tjahjaningsih, E. (2015). Pengaruh Employee Engagement dan Modal Sosial terhadap Kinerja Karyawan dengan OCB (Organizational Citizenship Behaviour) sebagai Mediasi (Studi pada Bank Jateng Kntor Pusat).

6. Gomes, Faustino Cardoso, 2010, Manajemen Sumber Daya Manusia, Penerbit Andi, Yogyakarta.

7. Hakim, Rahmat Budi. 2014. Manajemen dan Evaluasi Kinerja Karyawan, edisi pertama, cetakan pertama. Jakarta: Aswaja Pressindo.

8. lbrecht, S. (2010). Handbook of Employee Engagement: Perspectives, Issues, Research and Practice. UK: Edward elgar publishing limited.

9. Lamatenggo,Nina. 2012. Teori Kinerja dan Pengkurannya. Jakarta: PT Bumi Aksara.

10. I Putu S Nugraha dan I GustiAyu D Adnyani, 2018, "Pengaruh Budaya Organisasi, Komitmen Organisasi terhadap Organizational Citizenship Behavior Sekretariat Daerah Kota Denpasar “ E-Jurnal Manajemen Unud, Vol. 7, No. 1, 2018: 1-28 ISSN : 2302-8912.

11. Indarti, S., Solimun, .Fernandes, A. and Hakim, W. 2017, "The Effect of OCB in Relationship Between Personality, Organizational Commitment and Job Satisfaction on Performance", Journal of Management Development, Vol. 36 No. 10, pp. 1283-1293. ISSN: 0262-1711.

12. Macey, W.H., Schneider, B., Barbera, K.M \& Young, S.A. (2009). Employee Engagement: Tools for Analysis, Practice, and Competitive Advantage. USA: John Wiley \& Sons.

13. Mahmud Fatoni, 2018, "The Role of OCB in Mediating the Effect of Employee Engagement and Organizational Commitment on Employee Performance: Contract vs Permanent Employees “, International Journal of Scientific Research and Management, Volume,06, No.08, p. |EL-2018-568-569. ISSN (e): 2321-3418.

14. María Zayas-Ortiz, Ernesto Rosario Eulalia, Marquez Pablo Colón Gruñeiro , 2015, "Relationship Between Organizational cCommitments and Organizational Citizenship Behaviour in a sample of private banking employees ", International Journal of Sociology and Social Policy, Vol. 35 ISS 1/2 pp. $91-106$.

15. Oktriadini, NR. 2015. Jurnal Manajemen Sumberdaya Manusia.

16. Otto Randa Payangan, Yohanes Rante, Ruben Tuhumena, Anita Erari, and Marcy Rita. 2018. "Moderating effect of organizational citizenship behavior on the effect of organizational commitment, transformational leadership and work motivation on employee performance". International Journal of Law and Management, Vol. 60 Issue: 4, pp.953-964.

17. Perera, G.D.N., Khatibi, A., Navaratna, N. and Chinna, K. (2014), "Job satisfaction and job performance among factory employees in apparel sector”, Asian Journal of Management Sciences \& Education, Vol. 3 No. 1, pp. 96-104.

18. Podsakoff, P. M., MacKenzie, S. B., Paine, J. B., \& Bachrach, D. G. (2000). Organizational Citizenship Behaviors: A critical review of the theoretical and empirical literature and suggestions for future research. Journal of Management, 26(3), 513-563.

19. PT. Bank SulutGo, 2018, Annual Report : Strong Commitment \& Continus Innovation.

20. Robbins, Stephen P and Judge, Timothy A. 2013. Organizational Behavior Edition 15. New

21. Robbins, Stephen. 2001. Perilaku Organisasi. Salemba Empat; Jakarta.

22. Robinson, I. (2006) Human Resource Management in Organizations. London, CIPD.

23. Schaufeli, W.B and Bakker, A.B. (2010). Job demands, job resources, and their relationship with burnout and engagement: a multi-sample study, Journal of Organizational Behavior, Vol. 25, pp. 293-315.

24. Schaufeli, W. B. \& Bakker, A. B. (2003). Job Demands, Job Resources, And Their Relationship With Burnout And Engagement: A Multi-Sample Study. Journal of Organizational Behavior. Vol. 25: hal. 293.

25. Sinambella, PoltakLijan. 2012. Kinerja Karyawan Teori Pengukuran dan Implikasi, Edisi Pertama, Cetakan Pertama. Jakarta: Graha Ilmu.

26. Sugiyono. 2014. Metode Penelitian Kuantitatif, Kualitatif, dan R\&D. Bandung: Penerbit Alfa beta.

27. Swati Dhird and Archana Shukla. 2019. Role of organizational image in employee engagement and performance", Benchmarking: An International Journal. Emeraldinsight.

28. Wibowo. 2015. Perilaku Dalam Organisasi edisi ke 2. Jakarta : Rajawali Pers.

29. Nafi, M., Supriadi, B., \& Roedjinandari, N. (2018). Internal Marketing Impact On Pine Forest ( $\mathrm{Spf}$ ) Tourist Atraction. IOSR Journal of Business and Manag..... Service Quality In Semeru https://doi.org/10.9790/487X-2007016672 